The Nature of Work 


\begin{abstract}
Also by Paul Thompson
Working the System: New Technology and the Shop Floor (with Eddie Bannon)

Work Organisation: A Critical Introduction (with David McHugh: forthcoming)
\end{abstract}




\title{
The Nature of Work
}

\author{
An introduction to debates \\ on the labour process
}

Second Edition

Paul Thompson

palgrave 


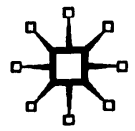

All rights reserved. No reproduction, copy or transmission of this publication may be made without written permission.

No paragraph of this publication may be reproduced, copied or transmitted save with written permission or in accordance with the provisions of the Copyright Act 1956 (as amended), or under the terms of any licence permitting limited copying issued by the Copyright Licensing Agency, 33-4 Alfred Place, London WC1E 7DP.

Any person who does any unauthorised act in relation to this publication may be liable to criminal prosecution and civil claims for damages.

First edition 1983

Reprinted 1984, 1985, 1986, 1988

Second edition 1989

Published by

MACMILLAN EDUCATION LTD

Houndmills, Basingstoke, Hampshire RG21 2XS

and London

Companies and representatives

throughout the world

Typeset in Great Britain by

Styleset Limited

Salisbury, Wiltshire

ISBN 978-0-333-49504-9 ISBN 978-1-349-20028-3 (eBook)

DOI 10.1007/978-1-349-20028-3

\section{To Betty and John \\ Elsie and Reg}




\section{Contents}

Preface to the First Edition

Preface to the Second Edition

ix

Glossary of Labour Process Terms xiii

Introduction

PART ONE THE ESTABLISHED TRADITIONS

1 The Sociological Study of Work 11

Workplace Behaviour 13

Origins of industrial sociology $\quad 14$

Post-war plant sociology $\quad 15$

Technology, work organisation and alienation: a critique

Organisation, Hierarchy and Control 23

Bureaucracy and capitalism 25

Radical perspectives $\quad 28$

Class, Work and Industrial Society 29

Orientations to work $\quad 30$

Post-industrial societies $\quad 32$

Conclusion: Contrasts and Continuities $\quad 34$

2 Marx and the Idea of the Labour Process 38

The General Character of the Labour Process 38

The Capitalist Labour Process $\quad 40$

From the workshop to large-scale industry 43

The division of labour 44

Mechanisation and its effects $\quad 46$ 
Theory and Reality: a Reflection

One Step Backwards: Explaining the Drift from the Labour Process

Politics and the workplace

Already existing socialism

Conclusion

\section{PART TWO THE CONTEMPORARY DEBATES}

3 Braverman and the Re-discovery of the Labour Process

New Beginnings: Theory and Practice

The Degradation of Work: The Braverman Thesis

Taylorism and control

Deskilling: science and technology in the service of capital

From production to society

The class structure

Conclusion

4 Deskilling: The Degradation of Labour?

Craft: Destruction and Resistance $\quad 92$

The perspective $\quad 93$

The critique $\quad 95$

The Theoretical Issues $\quad 100$

Labour markets and capitalist development $\quad 101$

Worker resistance, skill and job control 106

The Contemporary Restructuring of Work 108

Motive forces for change 109

The application of new technology 111

The persistence of limits to deskilling 115

Conclusion: The Unsubstantiated Connections 118

5 Forms of Control and Resistance 122

The Origins of Capitalist Control 123

The Development of Systematic Management 126

Taylorism reassessed 
The Frontier of Control

Direct control and responsible autonomy $\quad 134$

The significance of job enrichment 138

A new frontier? 143

Contested Terrain: The Edwards Thesis 144

Managerial experiments 144

Interrelations between modern control structures $\quad 146$

Conclusion: The Dimension of Control 150

6 Legitimation and Consent in Work 153

Work and Consciousness: Alternative Problematics 155

Traditional Marxism $\quad 155$

Sociology $\quad 157$

The Manufacture of Consent $\quad 159$

Games and practices 160

From coercion to consent? 163

The Limits to Workplace Consent $\quad 165$

The perpetuation of conflict $\quad 167$

The Relevance of External Factors $\quad 170$

Class, culture and trade unionism 172

The social preparation for work $\quad 175$

Conclusion: Integrating Consent $\quad 176$

7 The Other Division of Labour 180

Women: Labour Market and Labour Process $\quad 181$

Opportunity and inequality 182

The academically invisible woman? 184

The Application of Marxist Categories $\quad 187$

Marx and female wage labour 188

Braverman: the feminist critique $\quad 190$

An industrial reserve army? 192

Conclusion 195

Patriarchy and Capital 196

The parameters of partnership 198

The Family, Wages and Work 201

The feminisation of jobs 203

The consolidation of women's work 205

Recent trends 206

Conclusion: The Analysis of Stratification 207 
PART THREE THEORETICAL ISSUES AND CHALLENGES

8 Towards a Core Theory 213

New Forms of Work Organisation 214

The Deskilling Debate Revisited 214

From flexible specialisation to Japanisation:

a new work organisation paradigm? 218

Or new wine in old bottles? 224

Conceptualising Control $\quad 229$

Capital, Labour and Managerial control 231

Reconstructing a case for control 234

The Core Theory 241

Retraining the Boundaries of Analysis 246

End-notes $\quad 251$

A Short Guide to Labour Process Literature $\quad 274$

$\begin{array}{ll}\text { Bibliography } & 278\end{array}$

Index $\quad 299$ 


\section{Preface to the First Edition}

My interest in the labour process first developed in political activity with shop stewards and shopfloor workers in the motor industry on Merseyside in the early 1970s. The experiences of the restructuring of work and pay began to be put to academic use in subsequent years of part-time research at Liverpool University. At first most of the innovative writings on the changing nature of work and class derived from Italy and France. All that changed with the publication of Braverman's Labor and Monopoly Capital in 1974, and the explosion of interest in the labour process that followed in its wake.

My research became increasingly directed towards tying together and evaluating the new debates, comparing them with older sociological traditions. This book draws on the knowledge I gained in those years, although its scope, aims and content are very different. I owe a considerable debt to Tony Lane for his encouragement and support through that period. Richard Hyman, too, was kind enough to give me some very useful advice which helped me to revise a number of my ideas about labour process theory and its limitations.

In working on the present book, my thanks go to Theo Nichols for a set of fair and useful comments on the whole manuscript, and to Dave Robertson and Lynne Segal for looking at particular chapters. I have continually drawn on the advice and knowledge of Mike Jones, the discussions between us contributing considerably to the development of my own ideas. In addition, the critical attention of Hazel Davies to the style of the manuscript has greatly added to its 
readability. My editor at Macmillan, Steven Kennedy, has also been an invaluable source of help in improving its form and content. Responsibility in all respects remains, of course, my own.

Thanks also go to Jean Pearson for work on the bibliography and index; and while most of the typing of the manuscript was my own, Tricia Houghton was kind enough to help with some of the chapters. Most of all, I would like to record my debt to Jill and our daughter Jane who have tolerated what often appeared to be endless periods of work on the book and its forerunners. Without their support such efforts could never have been completed.

Liverpool

PAUL THOMPSON

December 1982 


\section{Preface to the Second Edition}

Many people influenced and helped me in preparing this second edition. The feeling that there is a distinctive labour process debate has been greatly facilitated by the Annual Aston-UMIST Conference on the Organisation and Control of the Labour Process. These conferences have allowed me and many others to receive feedback and test ideas in a sympathetic and critical environment. David Knights and Hugh Wilmott deserve considerable credit for putting in the practical and intellectual work to make this happen.

Graeme Salaman and Stephen Wood have encouraged and supported my work; and Peter Armstrong's humour, penetrating analysis and commitment has helped keep me sane and on the right path.

Fairly soon after the publication of the first edition, I moved to Lancashire Polytechnic. My colleagues there have been consistently supportive. I would particularly like to thank Jim McGoldrick. Whenever ideas needed exploring, I have been able to pop next door to continue our increasingly similar intellectual journey. I hope that I've been as useful to Jim as he has been to me. My students, too, especially on the 'People and Work' course, have provided valuable feedback.

Visting the Institute of Advanced Studies in Vienna during 1987 gave me a chance to put many of my ideas in order and enable them to be given a much-needed critical jolt. I would particularly express my thanks to Georg Aichholzer, Gerd Schienstock and Jorg Flecker. 
xii

My family have again supported me and put up with a disappearing act, though this time of a mercifully shorter duration. Finally I would like to thank Victoria Yogman and Steven Kennedy at Macmillan for their advice and encouragement in getting out this second edition.

A ugust 1988

PAUL THOMPSON 


\section{Glossary of Labour Process Terms}

The aim of this glossary is not to produce a set of definitions for the complete range of sociological and Marxist concepts, but rather to deal with those terms used throughout the text which have specific relevance to the labour process.

alienated work Work performed under conditions in which the worker is estranged from his or her own activity in the act of production, through the sale of labour power and the subordination of skills and knowledge to the capitalist, or other external social forces.

automation A form of production in which all manual intervention by the worker is eliminated, in some cases to be replaced by supervision, monitoring or control of machinery. It includes a number of types such as continuous process, numerical control and automated assembly; and is distinguished from mechanisation, which concerns the operation of tools or machinery through sources independent of the worker's manual dexterity.

capitalism A mode of production based on the generalised production of commodities for exchange and profit. collective worker At a certain stage of capitalist production, manual and intellectual workers are combined together in association by the machine system. The term is used to stress the partial interchangeability of functions, and the potential for genuine co-operation in the labour process in a socialist society. See also homogenisation. 
control system Mechanisms by which employers direct work tasks, discipline and reward workers, and supervise and evaluate their performance in production. See also subordination.

deskilling Incorporation of the crafts, knowledgeable practices and elements of job control held by workers into the functions of management, or operation of machinery.

division of labour This is not the existence of different jobs, but the simplifying and fragmentation of tasks into smaller parts, so as to cheapen and control the costs of labour. Marx also uses a distinction between this technical division and the social division of labour, related to wider societal processes through which workers are allocated to different branches of production. This has relevance to the analysis of relations between social hierarchies of race and sex, and hierarchies in work.

fetishism The process in production whereby the workings of the market, exploitation and private ownership appear as natural and inevitable rather than social relations capable of transformation.

forces and relations of production $A$ distinction between skills, machinery and other physical properties of production, and the social relations of ownership, command and control. These are held by Marx to act constantly on one another, enabling a critique to be made of those who believe that science and technology are neutral.

Fordism A term used by some labour process theorists which extends the technique of factory production - based on the assembly-line - developed by Ford into a category referring to a general stage in capitalist production.

homogenisation Controversial term used by Marx and other labour process writers to refer to the equalisation of types of work under the impact of deskilling and related trends.

intellectual and manual labour All human labour involves mind and body, but this concept is used to describe the separation of conception and execution that is built into the design of jobs, reflecting the objectives of capital.

job enrichment One form of work humanisation by employers. It is often used as a generic description of a number of different processes of enlarging, aggregating and rotating tasks. 
labour market The means of alloçating and pricing jobs in the economy as a whole, and within particular firms (an internal labour market).

labour power The capacity to work which is transformed into labour that produces value for the capitalist through the creation of commodities.

labour process The means by which raw materials are transformed by human labour, acting on the objects with tools and machinery: first into products for use and, under capitalism, into commodities to be exchanged on the market.

large-scale industry A term used by Marx to distinguish between the mature factory system in which the labour process is transformed by the uses of science and machinery, and previous stages such as manufacture (dominated by the introduction of the division of labour), and cooperation (characterised by the concentration of workers into the same or connected processes by the capitalist).

reproduction of labour power The wider means of ensuring the continuity of wage labour through the organisation of the fundamental material and social needs of human life food, clothing, leisure, etc. This is a crucial part of connections between the labour process and institutions such as the family.

reserve army of labour What Marx described as a relative surplus population of unemployed workers, or potential workers - such as the sporadically employed, housewives and migrants - who form a necessary part of the working mechanisms of the capitalist mode of production.

subordination of labour Marx used these terms in a more precise way than that of control. The formal subordination of labour is established when workers and their skills are subsumed in a labour process under the control of the capitalist. This is ultimately transformed into real subordination through the incorporation of science and machinery within the expanded scale of production - which, in turn, allows a qualitatively new and more effective means of domination of labour.

Taylorism Management control strategy named after F. W. Taylor. The first systematic theory and practice of management, its defining characteristic has been the attempt to 
separate mental and manual labour, subjecting both to exact measurement. Taylorism spawned a more general movement known as scientific management.

valorisation The process of creating surplus value. The labour process only becomes distinctively capitalist when it is combined with valorisation.

worker resistance A widely used term by labour process writers to refer to informal and organised worker opposition to management and employers in the labour process. It is more specific to work than the of ten misleading application of the concept of 'class struggle'. 